\title{
STRATEGI BERTAHAN HIDUP PENGHUNI PEMUKIMAN KUMUH
}

\author{
Afriyani Simanjuntak \\ Alumni Prodi. Pendidikan Antropologi Fakultas Ilmu Sosial Universitas Negeri Medan \\ Bakhrul Khair Amal \\ Staf Pengajar di Prodi. Pendidikan Antropologi Fakultas Ilmu Sosial Universitas Negeri Medan \\ b4khrul.4m4l@gmail.com
}

\begin{abstract}
Abstrak
Arus urbanisasi yang pesat di perkotaan ditandai oleh timbulnya pemukiman-pemukiman kumuh menggambarkan kemiskinan suatu daerah. Banyak anggapan masyarakat bahwa kumuh identik dengan kemiskinan. Kondisi lingkungan yang kotor dan bau tak sedap serta bentuk rumah yang mereka tempati, secara fisik dapat dikategorikan masyarakat miskin. Berkaitan dengan hal tersebut penelitian ini bertujuan untuk mengidentifikasi dan menganalisis karakteristik kemiskinan serta strategi-strategi yang dilakukan untuk bertahan hidup di pemukiman kumuh bantaran rel kereta api Kelurahan tegal Sari Mandala II Medan. Penelitian ini merupakan penelitian kualitatif yang bersifat deskriptif yaitu teknik penelitian yang memaparkan data yang ada berdasarkan fakta yang ada di lapangan. Pelaksanaan penelitian ini dilakukan melalui penelitian lapangan (field research) dengan metode observasi, wawancara dan dokumentasi. Dari hasil penelitian lapangan bahwa kemiskinan yang terjadi di pemukiman kumuh bantaran rel kereta api Kelurahan Tegal Sari Mandala II Medan adalah kemiskinan yang terjadi karena faktor individual dan struktural yang kerap menjerat mereka dalam lingkaran kemiskinan. Hambatan-hambatan struktural yang menjerat di perkotaan membuat mereka untuk mengambil pilihan untuk bekerja dalam lingkup starta sosial rendah di perkotaan. Motif warga di kawasan pemukiman bantaran rel memilih untuk tinggal di kawasan tersebut adalah karena daerah atau kawasannya startegis bagi mereka untuk memelihara hewan berkaki empat (babi). Karena jauh dari wilayah perkotaan (pinggiran kota) mereka memilih untuk mempertahankan dan meingkatkan perekonomian keluarga dengan beternak babi dan bekerja sebagai pemulung. Butuh strategi untuk mencoba keluar dari jerat kemiskinan yang sulit untuk dilepas bagi masyarakat miskin di perkotaan. Pandangan pihak luar merupakan tindakan irrasional, dalam kenyataannya, mungkin merupakan satu-satunya pemecahan dari himpitan kesulitan sosial ekonomi. Adapun strategi atau yang digunakan adalah dengan meningkatkan asset dengan melibatkan lebih banyak anggota keluarga untuk bekerja, memulai usaha kecil-kecilan, memulung barang-barang bekas, menyewakan kamar, menggadaikan barang, meminjam uang di bank atau lintah darat. Meningkatkan asset merupakan salah satu cara untuk mengatasi berbagai permasalahan yang melingkupi kehidupannya.
\end{abstract}

Kata Kunci: Strategi, Perkotaan, Irrasional, kemiskinan

\section{PENDAHULUAN}

Persoalan permukiman merupakan masalah yang serius karena dikhawatirkan akan menyebabkan terjadinya kantong-kantong kemiskinan yang fatal dan kemudian menyebabkan lahirnya berbagai persoalan sosial di luar kontrol atau kemampuan pemerintah kota untuk menangani dan mengawasinya. Permukiman kumuh merupakan salah satu masalah sosial di Indonesia yang tidak mudah untuk diatasi. Hal ini mendapat sorotan dari para sosiolog dan antropolog ialah masalah kemiskinan yang dialami oleh golongan tertentu di kotakota besar. Kota yang mempunyai hampir semua fasilitas untuk meningkat taraf dan kualitas hidup penghuninya, namun masih saja terdapat kelompok masyarakat yang hidup dalam keadaan menyedihkan atau tidak sesuai dengan standar hidup yang layak.

Kota belum mampu untuk memberikan lapangan kerja kepada pendatang-pendatang baru tersebut, yang biasanya terdiri dari orang-orang yang rendah pendidikannya, kurang mempunyai keterampilan dan kurang modal (Sunartiningsih, 2000). Dengan demikian mereka sulit untuk mendapatkan pekerjaan memadai di kota. Pada akhirnya mereka mengerjakan pekerjaan apa saja asal dapat mempertahankan kelangsungan hidup mereka. Penghasilan mereka rendah dan penuh ketidakpastian. Mereka inilah yang termasuk golongan miskin di kota.

Kehidupan mereka yang tergolong miskin tersebut merupakan masalah sosial akibat terjadinya ketidakcukupan materi atau uang untuk memenuhi kebutuhan hidup mereka, termasuk biaya pendidikan dan tempat bermukim. Maka kawasan kumuhpun muncul di kota-kota besar. Pemukiman ini justru menjadi beban bagi pemerintah untuk selalu diberikan bantuan dalam bentuk materi.

Survival berasal dari bahasa inggris survive atau to survive yang artinya bertahan hidup. Yang dimaksud 
disini adalah kemampuan untuk dapat bertahan hidup. Survival dapat juga diartikan sebagai upaya untuk mempertahankan hidup dan keluar dari keadaan yang sulit (mempertahankan diri dari keadaan tertentu/ keadaan dimana diperlukan perjuangan untuk bertahan hidup). Sedangkan menurut pengertian lain survival adalah suatu kondisi dimana seseorang atau kelompok orang dari kehidupan normal (masih sebagaimana direncanakan) baik tiba-tiba atau disadari masuk kedalam situasi tidak normal atau diluar garis rencananya.

Secara umum strategi bertahan hidup dapat didefenisikan sebagai kemampuan seseorang dalam menerapkan seperangkat cara untuk mengatasi berbagai permasalahan yang melingkupi kehidupannya.

Sondang Siagian, mengemukakakan bahwa konsep strategi merupakan salah satu alat yang tersedia bagi manajemen puncak untuk menghadapi segala perubahan yang terjadi, baik yang sifatnya eksternalm terhadap organisasi maupun yang sifatnya internal. Suatu strategi merupakan cara yang sifatnya mendasar dan fundamental yang akan dipergunakan oleh suatu organisasi untuk mencapai tujuan dan berbagai sasarannya dengan selalu memperhitungkan kendala lingkungan yang pasti akan dihadapi (Wignjosoebroto, 2005).

\section{Pengertian Pemukiman Kumuh}

Tumbuhnya pemukiman kumuh diakibatkan oleh migrasi dan juga urbanisasi. Masyarakat desa merasa bahwa kota merupaka tempat bagi mereka untuk meningkatkan taraf kehidupan mereka. Hidup di kota sebagai warga dengan mata pencaharian terbanyak pada sector informal.

Secara umum, daerah kumuh (slum area) diartikan sebagai suatu kawasan pemukiman atau pun bukan kawasan pemukiman yang dijadikan sebagai tempat tinggal yang bangunan-bangunannya berkondisi substandar atau tidak layak yang dihuni oleh penduduk miskin yang padat. Kawasan yang sesungguhnya tidak diperuntukkan sebagai daerah pemukiman di banyak kota besar, oleh penduduk miskin yang berpenghasilan rendah dan tidak tetap diokupasi untuk dijadikan tempat tinggal, seperti bantaran sungai, di pinggir rel kereta api, tanahtanah kosong di sekitar pabrik atau pusat kota, dan di bawah jembatan.

Beberapa ciri-ciri daerah kumuh (dalam Menno : 1994) antara lain:

1. Dihuni oleh penduduk yang padat dan berjubel, baik karena pertumbuhan penduduk akibat kelahiran mapun karena adanya urbanisasi.

2. Dihuni oleh warga yang berpenghasilan rendah dan tidak tetap, atau berproduksi subsisten yang hidup di bawah garis kemiskinan.
3. Rumah-rumah yang ada di daerah ini merupakan rumah darurat yang terbuat dari bahan-bahan bekas dan tidak layak.

4. Kondisi kesehatan dan sanitasi yang rendah, biasanya ditandai oleh lingkungan fisik yang jorok dan mudahnya tersebar penyakit menular.

5. Langkanya pelayanan kota seperti air bersih, fasilitas MCK, listrik, dsb.

6. Pertumbuhannya yang tidak terencana sehingga penampilan fisiknya pun tidak teratur dan tidak terurus; jalan yang sempit, halaman tidak ada, dsb.

7. Kuatnya gaya hidup "pedesaan" yang masih tradisional.

8. Secara sosial terisolasi dari pemukiman lapisan masyarakat lainnya.

9. Ditempati secara ilegal atau status hukum tanah yang tidak jelas (bermasalah).

10. Biasanya ditandai oleh banyaknya perilaku menyimpang dan tindak kriminal.

\section{Konsep Kemiskinan}

Secara konseptual bahwa kemiskinan bisa diakibatkan oleh empat factor (Suharto, 2009), yaitu :

1. Faktor Individual

Terkait dengan aspek patologis, termasuk kondisi fisik dan psikologis si miskin. Orang miskin disebabkan oleh prilaku, pilihan, atau kemampuan dari si miskin itu sendiri dalam menghadapi kehidupannya.

2. Faktor Sosial

Kondisi-kondisi lingkungan sosial yang menjebak seseorang menjadi miskin. Misalnya diskriminasi berdasarkan usia, jender, etnis yang menyebabkan seseorang menjadi miskin. Termasuk dalam faktor ini adalah kondisi sosial dan ekonomi keluarga si miskin yang biasanya menyebabkan kemiskinan antar generasi.

3. Faktor Kultural

Faktor ini secara khusus sering menunjuk pada konsep "kemiskinan kultural" atau "budaya kemiskinan" yang menghubungkan kemiskinan dan kebiasaan hidup atau mentalitas. Sikap-sikap negatif seperti malas, fatalism atau menyerah kepada nasib, tidak memiliki jiwa wirausaha, dan kurang menghormati etos kerja misalnya sering ditemukan pada orang-orang miskin.

4. Faktor Struktural

Menunjuk pada struktur atau sistem yang tidak adil, tidak sensitif dan tidak accessible sehingga menyebabkan seseorang atau sekelompok orang menjadi miskin. Sebagai contoh, system ekonomi neoliberalisme yang diterapkan di Indonesia telah menyebabkan para petani, nelayan dan pekerja 
sektor informal terjerat oleh, dan sulit keluar dari, kemiskinan. Sebaliknya stimulus ekonomi, pajak dan iklim investasi lebih menguntungkan orang kaya dan pemodal asing untuk terus menumpuk kekayaan.

Berdasarkan kondisi kawasan kumuh di sepanjang bantaran rel kereta api yang diteliti, maka penelitian ini memfokuskan penyebab kemiskinan dari faktor individual dan faktor struktural. Selo Soemardjan (Wignjosoebroto, 2009) memisahkan antara kemiskinan individu yaitu kemiskinan yang dialami oleh seorang individu karena dia malas bekerja atau oleh karena dia terus menerus sakit; dengan kemiskinan struktural yaitu kemiskinan yang diderita oleh suatu golongan masyarakat karena struktur sosial masyarakat itu tidak dapat ikut menggunakan sumber-sumber pendapatan yang sebenarnya tersedia bagi mereka.

\section{Teori Slum}

Slum bisa dikategorikan kepada suatu lingkungan berdasarkan tingkat kemakmuran yang dapat diberikan area itu kepada penghuninya ( terutama di desa). Kalau lingkungan itu miskin karena ketandusan tanahnya maka cenderung akan terjadi slum ( Simanjuntak, 2008 : 33 ). Pendapat ini terlihat bahwa slum terjadi apabila lingkungan itu miskin dan penghuninya termasuk dalam golongan miskin. Standard penggolongan miskin di sini didasarkan pada sistem perumahan atau housing maupun cara penggunaan fasilitas di perumahan yang ada.

Ada beberapa landasan lain untuk memnetapkan standar slum ini diantaranya penggunaan waktu terlarang, jenis hubungan, jenis makanan sehari-hari, bentuk pergaulan sosial, ketegangan dan ketenangan yang disebabkan gossip dan sebagainya ( Simanjuntak 2008 : 34 ). Bila teori ini diperhadapkan dengan kondisi di daerah pemukiman sepanjangan bantaran rel kereta api Kelurahan Tegal Sari Mandala II, Medan sering terlihat bahwa plastik-plastik bekas dan juga botol-botol bekas yang menumpuk bahkan bau tak sedap yang disebabkan oleh pekerjaan mereka sebagai peternak babi.

\section{Teori Strategi Survival}

Secara teoritis maupun praktis, perkembangan teori survival strategy telah memperoleh pengakuan oleh berbagai kalangan masyarakat di dunia karena analisisnya mampu menjawab kebutuhan hidup manusia, kelompok, suku bangsa, bangsa dan Negara agar kelangsungan hidup (survive) menjadi pilihan aktif kalau tidak ingi mengalami kepunahan. Teori survival strategy yang dikembangkan oleh Chyntia Kenyon dan Claire Cockcroft (2008) tentang surving longer (kelangsungan hidup menyelamatkan nyawa lebih panjang). Teori surving longer berarti perlu ada usaha secara individual, kelompok, bangsa maupun Negara agar usia harapan hidup pada manusia menjadi sangat penting sehingga diperlukan cara konsumsi bahan-bahan kebutuhan hidup, air dan sebagainya memiliki kaitan langsung dengan kelangsungan hidup jangka panjang.

Moser dalam Jurnal Survival Mechanism Victim Housland of Lumpur Lapindo in Sidoarjo, Jawa Timur menyatakan bahwa strategi bertahan hidup merupakan kemampuan segenap anggota keluarga dalam mengelola atau memanage berbagai asset yang dimilikinya. Berdasarkan konsep ini, Moser membuat kerangka analisis yang disebut The Asset Vulnerability Framework Kerangka ini meliputi berbagai pengelolaan aset, (1) aset tenaga kerja (labour assets), misalnya meningkatkan keterlibatan wanita dan anak-anak dalam keluarga untuk bekerja membantu ekonomi rumah tangga. Sama hal nya dengan masyarakat miskin di bantaran rel dimana anakanak mereka harus ikut membantu orangtua mencari plastik-plastik dan botol-botol bekas di pinggiran jalan. Sehingga pendidikan anak-anak merekapun menjadi terbengkalai. (2) aset modal manusia (human capital assets), misalnya memanfaatkan status kesehatan yang dapat menentukan kapasitas orang untuk bekerja atau keterampilan dan pendidikan yang menentukan kembalian atau hasil kerja (return) terhadap tenaga yang dikeluarkannya. (3) asset produktif (productive assets), misalnya menggunakan rumah, sawah, ternak, tanaman untuk keperluan hidupnya, seperti ternak babi yang dijadikan sebagai mata pencaharian untuk keperluan hidup. (4) aset relasi rumah tangga atau keluarga (household relation assets), misalnya memanfaatkan jaringan dan dukungan dari sistem keluarga besar, kelompok etnis, migrasi tenaga kerja dan mekanisme "uang kiriman" (remittances), dan (5) aset modal sosial (social capital assets), misalnya memanfaatkan lembagalembaga sosial lokal, dan pemberi kredit informal dalam proses dan sistem perekonomian keluarga.

Scott menjelaskan upaya yang dilakukan kelompok miskin guna mempertahankan hidupnya adalah, pertama, mereka dapat mengikat sabuk lebih kencang dengan mengurangi frekuensi makan dan beralih ke makanan yang mutunya lebih rendah. Kedua, menggunakan alternatif subsistem yaitu swadaya yang mencakup kegiatan-kegiatan seperti berjualan kecilkecilan, bekerja sebagai tukang, buruh lepas atau berimigrasi. Ketiga, menggunakan jaringan sosial yang berfungsi sebagai peredam kejut selama masa krisis ekonomi.

Karl Marx yang memusatkan perhatiannya pada cara orang menyesuaikan dirinya dengan lingkungan fisiknya. Dia juga melihat hubungan-hubungan sosial yang muncul dari penyesuaian lingkungan dan melihat hubungan-hubungan sosial yang muncul dan tunduknya 
aspek-aspek kenyataan sosial dan budaya pada asas ekonomi . Pada kenyataannya, ide-ide bersifat "epifenomenal", artinya ide-ide itu merupakan cerminan dari kondisi kehidupan materil dan struktur ekonomi dimana orang menyesuaikan dirinya dengan kondisi itu. Seperti yang ditekankan Marx, tuntutan untuk mencari nafkah supaya bisa tetap hidup dapat memakan waktu dan energi sedemikian besarnya sehingga hampir tidak mungkin untuk mengembangkan kemampuankemampuan lainnya.

\section{HASIL DAN PEMBAHASAN}

Akses terhdap teknologi (informasi, telekomunikasi, dan transportasi) memungkinkan masyarakat perkotaan untuk lebih cepat mengetahui serta menerima perubahan dibandingkan dengan kelompik masyarakat lain. Maka tidak heran bahwa masyarakat perkotaan cenderung bersifat dinamis, yang cenderung rentan mengalami perubahan sosial. Akan tetapi, tidak semua lapisan masyarakat perkotaan dapat sedemikian mudah menyesuaikan diri terhadap perubahan, baik itu perubahan yang bersumber dari faktor internal maupun faktor eksternal, disengaja maupun tidak disengaja. Masyarakat miskin misalnya, memiliki keterbatasan dalam mencari dan menerapkan alternatif - alternatif untuk menyesuaikan diri dan bertahan hidup dalam perubahan sosial yang dinamis. Sehingga kerap muncul kesulitan-kesulitan yang dialami masyarakat miskin dalam menyesuaikan diri terhadap perubahan. Keadan serba kekurangan akibat pendapatan yang rendah dan tidak menentu karena hambatan struktural membuat rasa ketergantungan mereka kepada pemilik modal menjadi tinggi. Budaya hutang menghutang tak bisa di hindari. Uang yang mereka peroleh langsung habis untuk keperluan konsumsi sehari-hari atau keperluan lainnya. Berarti ada jaringan ekonomi yang kuat sehigga bila jaringan ekonomi ini diputus maka masing-masing pihak akan merugi. Maka mereka menjadi orang-orang yang tak berdaya dalam modal. Kemiskinan struktural pun akan terus terjadi dalam lingkungan tersebut.

Butuh strategi untuk mencoba keluar dari jerat kemiskinan yang sulit untuk dilepas bagi masyarakat miskin di perkotaan. Apa yang ada dalam pandangan pihak luar merupakan tindakan irrasional, dalam kenyataannya, mungkin merupakan satu-satunya pemecahan dari himpitan kesulitan sosial ekonomi. Adapun strategi atau yang yang digunakan adalah dengan meningkatkan asset dengan melibatkan lebih banyak anggota keluarga untuk bekerja, memulai usaha kecilkecilan, memulung barang-barang bekas, menyewakan kamar, menggadaikan barang, meminjam uang di bank atau lintah darat. Meningkatkan asset merupakan salah satu cara untuk mengatasi berbagai permasalahan yang melingkupi kehidupannya. Strategi penanganan masalah ini pada dasarnya merupakan kemampuan seseorang dalam menerapkan seperangkat cara untuk mengatasi berbagai permasalahan yang melingkupi kehidupannya. Termasuk bagaimana harus mempertahankan kelangsungan hidup yang dikuasai oleh oknum-oknum yang menjadikan masyarakat itu sendiri menjadi miskin.

Strategi penanganan masalah pada dasarnya merupakan kemampuan segenap anggota keluarga dalam mengelola atau mengelola berbagai asset yang dimilikinya. Bisa juga dipersamakan dengan kapabilitas keluaraga dalam menanggapai goncangan dan tekanan. Adapun pengelolaan asset yang dapat digunakan untuk melakukan penyesuaian dan pengembangan strategi tertentu dalam mempertahankan kelangsungan hidup yaitu:

\section{Aset Tenaga Kerja (Labour Asets)}

Melibatkan wanita dan anak-anak dalam keluarga untuk bekerja membantu ekonomi keluarga merupakan cara untuk mempertahankan kelangsungan hidup. Lakilaki seharusnya menjadi kepala keluarga yang memiliki tanggungjawab besar untuk memenuhi kebutuhan hidup keluarga sepenuhnya tidak tampak di kawsan kumuh lingkungan mandala II. Mengharapkan penghasilan dari suami tidak cukup untuk memenuhi kebutuhan hidup. Terutama bagi keluarga yang memiliki banyak anak. Untuk itu wanita pun ikut banting tulang membantu suami demi mencukupi ekonomi keluarga.

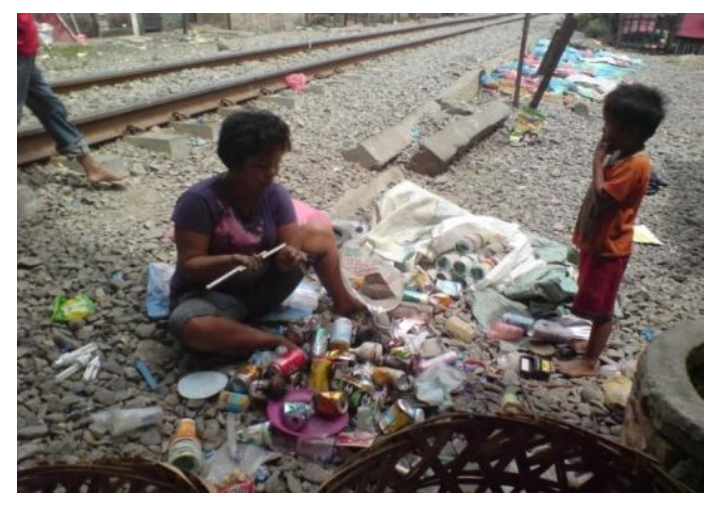

Gbr 3. Ibu Nurmala sedang membersihkan dan memilah botol-botol bekas

Seperti yang tampak pada gambar bahwa seorang wanita sedang membersihkan dan memilah-milah botol bekas yang telah ia kumpulkan di pinggiran jalan. Beliaua dalah Ibu Nurmala br Marbun (30), mengaku bahwa mengandalkan penghasilan dari suami tidaklah cukup. Suami ibu Nurmala sendiri berprofesi sebagai penarik becak. Mereka memiliki 3 orang anak. Anak menjadi asset yang sangat berharga bagi mereka. Keinginan untuk memperjuangkan anak-anak mereka 
agar menjadi orang sukses kelak merupakan sebuah impian yang ingin mereka wujudkan. Namun mereka tak ingin memanjakan anak-anak mereka. Untuk itu mereka mengajari anak-anak mereka untuk ikut bekerja membantu orangtua. Namun tanpa disadari anak menjadi asset bagi mereka untuk membantu ekonomi rumah tangga.

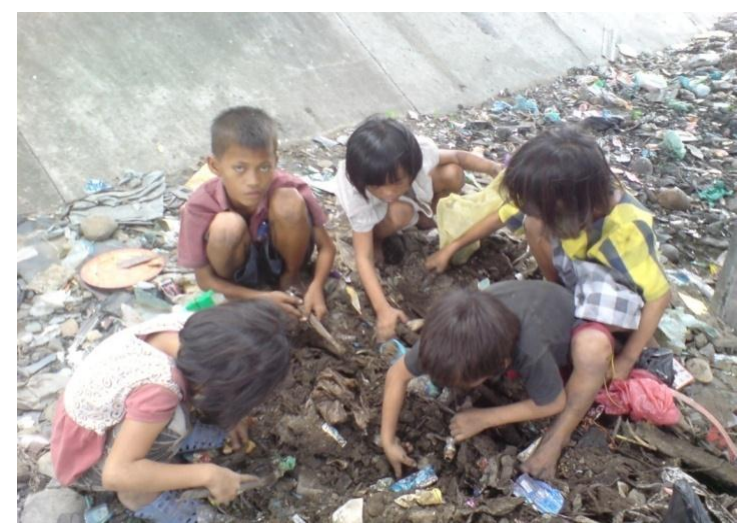

Gbr 4. Anak-anak mencari barang-barang bekas yang masi layak guna

Umumnya seluruh kasus penelitian yang menghuni lingkungan kumuh memandang bahwa hidup itu susah tapi mereka sadar mereka harus makan dan menyekolahkan anak-anak mereka sehingga mereka bekerja agar mereka bisa hidup layak. Mereka yakin hidup itu susah dan perlu perjuangan untuk menghadapinya karena mereka tidak bisa mengandalkan orang lain dalam hal mencari makan. Mereka sendirilah yang harus berusaha mengisi hidup dan masa depan mereka. Untuk mengatasinya mereka menghilangkan perasaan susahnya dengan semangat bekerja dan dibantu juga dengan semangat anak-anak mereka yang turut membantu orangtua mereka sendiri.

\section{Aset Modal Manusia (Human Capital Asets)}

Memanfaatkan status kesehatan yang dapat menentukan kapasitas orang untuk bekerja atau keterampilan dan pendidikan yang menentukan umpan balik atau hasil kerja (return) terhadap tenaga yang dikeluarkannya. Masyarakat batak Toba adalah kelompok masyarakat yang dikenal dengan watak atau sifat yang keras. Sehingga dalam bekerja, masyarakat batak Toba tidak memiliki sifat yang fatalistic dalam menjalani kehidupan. Sekalipun mereka harus bekerja dengan cara yang kotor seperti memulung, bukan menjadi masalah besar bagi mereka untuk bertahan hidup. Selama masih memiliki fisik yang kuat, masih bisa menggunakan tenaga-tenaga yang dimiliki untuk bekerja, maka apa saja dilakukan untuk mempertahankan kelangsungan hidup asal pekerjaan yang mereka lakukan adalah halal.
Tenaga merupakan modal besar bagi masyarakat di kawasan pemukiman. Karena memulung dan memelihara babi membutuhkan tenaga yang cukup. Setiap harinya mereka harus mendayung becak atau sepeda untuk mencari makanan babi sambil memulung barang-barang bekas. Dan ada pula dari mereka yang berjalan kaki untuk mencari barang-barang bekas.

Kesehatan merupakan harta yang paling berharga bagi mereka. Penulis mendapatkan orang-orang di kawasan pemukiman yang berusia lanjut justru masih memiliki tenaga yang kuat. Meski sudah tua, mereka masih tetap kuat untuk mendayung sepeda mencari makanan bekas untuk babi yang mereka pelihara.

\section{Aset Produktif ( Produktive Asets )}

Dengan menggunakan rumah, sawah, ternak, tanaman untuk keperluan hidupnya, dapat dijadikan sebagai mata pencaharian untuk keperluan hidup. Beberapa rumah di sepanjang bantaran rel merupakan rumah kontrakan. Meskipun mereka sudah memiliki rumah sendiri ada beberapa keluarga yang memiliki rumah kontrakan di sekitar bantaran rel. Rumah kontrakan juga menjadi asset bagi mereka untuk mecukupi kebutuhan ekonomi rumah tangga.

Hampir semua penduduk di kelurahan Tegal Sari Mandala II sepanjang bantaran rel kereta api adalah masyarakat Batak Toba. Sudah menjadi suatu hal yang biasa bila masyarakat batak Toba menambah penghasilan ekonomi keluarga dari beternak babi. Ternak babi merupakan asset jangka panjang bagi mereka. Dengan bekerja sebagai peternak babi tidak sedikit masyarakat Batak Toba mendapat kehidupan yang layak. Tak heran bila mereka dapat menyekolahkan anak-anak mereka sampai perguruan tinggi bahkan mencapai sebuah kesuksesan dalam karier.

Ibu Simatupang merupakan salah satu keluarga yang memiliki asset produktif cukup baik. Selain sebagai pemulung, beliau juga bekerja sebagai peternak babi. Setiap harinya beliau mencari nasi-nasi bekas atau disebut dengan "parnap" untuk makan babi-babi peliharaannya. Baginya jika mengandalkan gaji PNS suaminya tidaklah cukup untuk membiayai ke empat anaknya. Menjadi kepala rumah tangga sekaligus ibu bagi anak-anak merupakan hal yang tidak mudah untuk dijalani. Namun dengan kegigihannya ia dapat menyekolahkan anak-anaknya.

Ibu Simatupang (62) memiliki 4(empat) orang anak. Dua diantaranya sudah meraih gelar sarjana. Suaminya sudah meninggal sejak 10 tahun yang lalu. Sejak itu beliau harus banting tulang untuk menafkahi kebutuhan ekonomi keluarga. Suami Ibu Simatupang merupakan Pegawai Negeri Sipil (PNS). Namun sejak beliau meninggal, Ibu Simatupang harus lebih keras lagi 
dalam mencari nafkah. Anak-anak menjadi pendorong beliau untuk tetap semangat dalam bekerja. Bila hanya mengharapkan gaji pegawai dari peninggalan suaminya tidaklah cukup untuk memenuhi kebutuhan keluarga dan menyekolahkan anak-anaknya. Beliau merupakan salah satu masyarakat yang sudah lama menetap di pinggiran rel kereta api. Sudah lama pula ia juga memelihara babi. Sebelum suami beliau meninggal, Ibu Simatupang sudah memelihara babi namun tidak banyak. Namun sekarang demi menyekolahkan anak-anak beliau berusaha dengan kerasnya untuk memperbanyak ternaknya. Karena bagi beliau dengan beternak babi akan meraih untung yang cukup untuk biaya kehidupan sehari-hari.

\section{Aset Relasi Rumah Tangga atau Keluarga (Housland Relation Asets)}

Sebagian besar penghuni pemukiman kumuh memandang kaya atau miskinnya seseorang dilihat darin ukuran kaya harta. Mereka meyakini bahwa mereka adalah orang-orang miskin yang masih perlu kerja keras untuk bisa hidup. Meski demikian, mereka tidak ingin meminta pertolongan kepada orang kaya. Mereka cenderung pergi ke teman atau kerabat yang dianggap sama derajatnya.

Tetangga maupun keluarga menjadi asset berharga bagi mereka untuk tetap bertahan di kawasan kumuh. Ikatan keluarga menjadi agak pudar dan solidaritas meluas hingga terjadi perluasan hubungan dari keluarga inti kepada kerabat dikarenakan suku yang sama yaitu batak Toba. Hal ini terjadi karena anggapan sebagian orang bahwa beban mental yang didapat dari hubungan keluarga lebih banyak dibandingkan dengan kerabat atau teman.

\section{Aset Modal Sosial (Social Capital Asets)}

Dengan memanfaatkan lembaga-lembaga sosial lokal, arisan, dan pemberi kredit informal dalam proses dan system perekonomian keluarga. Maka menjadi asset sosial bagi mereka untuk mempertahankan kelangsungan hidup mereka. Karena di kawasan pemukiman ini adalahn masyarakat batak toba dan umumnya beragama nasrani maka mereka membentuk sebuah STM ( Serikat Tolong Menolong ) untuk kawasan pemukiman. Kegiatan dari gereja seperti kebaktian atau disebut dengan istilah "partangiangan" sering diadakan di rumah-rumah jemaat yang berlokasi di kawasan pemukiman.

Namun dengan keterbatasan dan kekurangan tersebut, mereka tetap berpikir positif dalam memandang hidup karena mereka mempunyai jaringan usaha ekonomi yang bisa diandalkan untuk kelangsungan pekerjaan mereka di dalam pemukiman tersebut. Orang-orang tersebut adalah pemilik warung yang bisa meminjamkan modal usaha dan memperbolehkan berhutang beras ataupun makanan lainnya serta pemilik rumah kontrakan. Para penghuni pemukiman kumuh itu sudah sangat senang tinggal di rumah mereka karena harganya yang murah dan menjadi tempat yang strategis dalam mengelola asset yang mereka miliki seperti memelihara babi.

Diantara mereka yang sudah terlibat dalam suatu ikatan kekerabatan akan merasa lebih senang meminjam uang dari anggota kelompoknya seperti kumpulan ibu arisan, kumpulan STM, dll. Fakta ini menunjukkan bahwa mereka membutuhkan orang lain untuk mendapat harpan dan semangat dalam hidup.

Hal-hal di atas merupakan asset modal sosial yang mereka miliki untuk bertahan dalam lingkungan pemukiman kumuh karena ada suatu ikatan kekerabatan yang kuat antar penghuni yang satu dengan yang lainnya dalam upaya bertahan hidup. Kebutuhan mereka akan keberadaan orang lain membuat semangat hidup mereka selalu tumbuh. Adanya sikap empati terhadap sesama menjadikan masyarakat untuk hidup saling terbuka. Tingkat kepercayaan yang tinggi terhadap sesama mejadi sebuah perlindungan bagi mereka yang terjerat dalam kemiskinan. Saling memiliki sifat bergantung terhadap sesama namun mereka masih memiliki sumber daya yang bisa diandalkan dan dikembangkan, yaitu tenaga dan jiwa usaha.

\section{Pengontrolan Konsumsi dan Pengeluaran}

Pada umumnya strategi atau cara yang dilakukan masyarakat miskin untuk dapat bertahan hidup adalah dengan mengurangi jenis pola makan, membeli barangbarang murah, mengurangi pengeluaran untuk pendidikan dan kesehatan, mengurangi kunjungan ke desa, memperbaiki rumah atau alat-alat rumah tangga sendiri. Penulis melihat bahwa kondisi di kawasan kumuh bantaran rel kereta api di kelurahan Tegal Sari Mandala II, Medan itu sendiri tampaknya sudah biasa melakukan pengontrolan konsumsi dan pengeluaran.

Pola makan yang tidak tentu dan seadanya serta perabot-perabot rumah tangga yang ada di rumah mereka, maka penulis dapat menarik kesimpulan bahwa mereka melakukan strategi pengontrolan konsumsi dan pengeluaran untuk dapat menghindari krisis ekonomi di daerah perkotaan.

Pendidikan merupakan suatu hal yang penting bagi masyarakat terutama pada penduduk pemukiman di kawasan Mandala II. Mereka melihat arti seorang anak bukan sebagai beban yang selalu menyusahkan mereka sehingga hanya cukup diberi makan tetapi dianggap sebagai sumberdaya keluarga yang dikembangkan untuk kemudian bisa membantu mereka dikemudian hariuntuk keluar dari kemiskinan atau memberikan suatu kebanggan tersendiri bagi mereka. Hal ini terlihat jelas 
dari harapan mereka terhadap anak-anak mereka dengan menyekolahkan mereka. Sebahagian penduduk yang masi tergolong miskin, anak-anak mereka dipekerjakan untuk mencari nafkah keluarga. Meskipun demikian, mereka tetap memberikan hak bagi anak-anaknya untuk mendapatkan pendidikan.

Menyekolahkan anak butuh modal yang besar pula. Biaya pendidikan tidaklah murah apalagi di kota. Adapun strategi yang mereka gunakan untuk menyekolahkan anak-anak mereka adalah dengan menyekolahkan anak-anak mereka di sekolah yang biayanya masih sesuai dengan standar perekonomian mereka. sekolah negeri merupakan salah satu target bagi mereka agar dapat menyekolahkan anak tanpa biaya yang besar. Karena di sekolah negeri sendiri pemerintah membuat bantuan operasional kepada anak-anak yang kurang mampu.

Mereka yang dapat menyekolahkan anak hingga sampai ke perguruan tinggi adalah mereka yang dengan sangat gigihnya untuk berjuang demi pendidikan anak. Strategi yang biasa dilakukan seperti dengan minyimpan atau menabung uang sedikit-demi sedikit dari memelihara babi. Dalam membeli barang-barang mereka lebih memperioritaskan barang-barang yang memang sangat dibutuhkan untuk keperluan sehari-hari.

Seperti yang dilakukan oleh Ibu Simatupang, beliau menabung sedikit demi sedikit dari gaji PNS suaminya dan ternak babi yang mereka miliki.hingga saat ini beliau dapat menyekolahkan anak-anaknya. Ibu Nurmala br Marbu juga melakukan hal yang sama. Dengan menabung dan mengatur keuangan rumah tangga merupakan hal yang harus dilakuakn untuk meminimalisir pengeluaran agar tetap dapat memenuhi kebutuhan hidup dan menyekolahkan anak mereka.

\section{Pengontrolan Jumlah Keluarga}

Anggapan banyak anak banyak rezeki masih melekat pada masyarakat pemukiman. Tanpa disadari justru memiliki anak yang banyak dapat mempersulit individu itu sendiri untuk lepas dari lembah kemiskinan. Meskipun anak dapat dijadikan aset untuk memperoleh penghasilan, namun di sisi lain mereka justru menambah pengeluaran. Menyekolahkan anak-anak bukanlah hal yang mudah. Jika anak-anak terbengkalai dalam pendidikan akibat orangtua yang tidak mampu menyekolahkan anak-anaknya maka sulit untuk keluar dari kemiskinan yang menjerat. Maka kemiskinanpun akan tetap mewarnai mereka.

Maka strategi yang mereka lakukan untuk meminimalisir pengeluaran dan berusaha untuk keluar dari jerat kemiskinan adalah dengan menitipkan anak ke kerabat atau keluarga lain baik secara temporer maupun permanen. Ibu Simatupang salah salah satu anaknya tinggal bersama opungnnya (nenek) di kampung yaitu Tarutung. Ibu Simatupang mengaku bahwa anaknya saat ini tinggal di kampung karena untuk menjaga dan merawat opungnya (nenek) yang sudah semakin tua. Namun ibu Simatupang sendiri tidak merasa bahwa dengan membawa anaknya ke kampung menjadi suatu strategi dalam pengubahan komposisi keluarga untuk mempertahankan kelangsungan hidup. Karena beliau sendiripun mengirimkan uang setiap bulannya ke kampung.

Begitu juga dengan ibu Nurmala yang memiliki anak masih berusia 1,5 tahun. Dimana ketika beliau bekerja untuk memulung setiap paginya atau pun terkadang di sore hari maka ia menitipkan anaknya ke tetangganya yang memiliki anak gadis untuk menjaga anaknya selama ia pergi bekerja.

\section{Karakteristik Kemiskinan di Bantaran Rel kereta Api}

Kemiskinan perkotaan telah menjadi 'model' dari perkembangan kota, dan juga merupakan masalah bagi pemerintahan dan manajemen perkotaan. Karena dari cara hidup para migran di perkotaan inilah telah lahir pola adaptasi, nilai-nilai yang diyakini, respons dalam tindakan/sikap, dan pola-pola kelakuan yang khas penduduk miskin kota yang oleh para ahlinya disebut dengan kebudayaan kemiskinan. Sama halnya pada masyarakat migran di kawasan pemukiman bantaran rel kereta api Kelurahan Tegal Sari mandala II Medan.

Kebudayaan kemiskinan merupakan suatu adaptasi atau penyesuaian dan reaksi kaum miskin terhadap kedudukan marginal mereka dalam masyarakat yang berstrata kelas di atas mereka, sangat individualistis berciri kapitalisme. Kebudayaan kemiskinan muncul karena faktor struktural. Dimana kemiskinan muncul bukan karena ketidakmampuan si miskin untuk bekerja (malas), melainkan karena ketidakmampuan sistem dan struktur sosial dalam menyediakan kesempatankesempatan yang memungkinkan si miskin dapat bekerja. Struktur sosial tersebut tidak mampu menguhubungkan masyarakat dengan sumber-sumber yang tersedia, baik yang disediakan oleh alam, pemerintah maupun masyarakat yang ada disekitarnya

Pihak yang berperan besar dari terciptanya kemiskinan struktural ini adalah pemerintah, karena pemerintah yang memiliki kekuasaan dan kebijakan cenderung membiarkan masyarakat dalam kondisi miskin, tidak mengeluarkan kebijakan yang pro masyarakat miskin, jikapun ada lebih berorientasi pada proyek, bukan pada pembangunan kesejahteraan.

Dari hasil penelitian bahwa kemiskinan yang terjadi di bantaran rel kereta api adalah kemiskinan yang terjaadi karena faktor individu yang merupakan faktor internal yang menghambat mereka keluar dari jerat 
kemiskinan.Dimana kondisi fisik dan psikologis si miskin disebabkan oleh prilaku, pilihan, atau kemampuan dari si miskin itu sendiri dalam menghadapi kehidupannya. Sehingga hal ini dapat menciptkan kebudayaan kemiskinan yang mencerminkan suatu upaya mengatasi rasa putus asa dan tanpa harapan, yang merpukan perwujudan dari kesadaran bahwa mustahil dapat meraih sukses di dalam kehidupan sesuai dengan nilai-nilai dan tujuan masyarakat yang lebih luas.

Namun adakalanya orang menjadi miskin bukan karena tindakan serta budaya yang melekat pada dirinya atau dalam masyarakat tetapi karena memang struktur yang ada dalam masyarakat tidak bisa meningkatkan orang-orang miskin ke tingkat kesejahteraan yang lebih baik. Sebaliknya, sikap orang yang secara obyektif disebut miskin tidak selamanya dan sepenuhnya berbudaya miskin karena mereka selalu berusaha untuk keluar dari kemiskinannya sehingga tidak memiliki sikap seperti yang ada dalam kebudayaan kemiskinan tersebut.

Pendidikan merupakan salah satu faktor untuk keluar dari jerat kemiskinan. Bagi mereka yang memiliki penghasilan rendah kesulitan untuk mendapatkan fasilitas pendidikan. Tidak sedikit dari mereka yang justru mengharapkan dan mencari bantuan untuk mendapatkan akses pendidikan terutama bagi anak-anak mereka. Bantuan yang di berikan oleh pemerintah secara rutin sudah diterapkan untuk diberikan kepada orang-orang miskin. Namun masih sering terjadi kecurangankecurangan di dalamnya.

Hasil wawancara dengan bebrapa informan menunjukkan bahwa sering terjadinya kesenjangan sosial yang mengakibatkan sulitnya untuk lepas dari jerat kemiskinan. Berarti ada faktor struktural atau proses tertentu yang menyebabkan mereka belum mampu menggunakan potensi nilai mereka untuk keluar dari kondisi miskinnya. Mereka sudah mampu berorientasi waktu ke masa depan dan memiliki kemampuan sertakemauan untuk bekerja keras. Namun mereka terbentur oleh keterbatasan modal yang dan keterampilan akibat ketidakmampuan orangtua mereka memperoleh pekerjaan yang berimbalan tinggi. Yang pada umumnya orangtua mereka adalah pemulung dan peternak babi yang berpenghasilan sedikit.

Mereka yang kurang dapat meraih kesempatan untuk bekerja di sektor formal yang berpendapatan rutin kerap mengalami hambatan. Hambatan ini berakar dari kekurangmampuan orangtua mereka dahulu untuk membiayai hingga sekolah tinggi sehingga mereka kurang pendidikan dan keterampilan. Jika mereka melakukan hal yang sama dengan generasi berikutnya, kualitas sumberdaya keluarga tidak berubah dan kemiskinan akan berlangsung secara terus menerus. Ternyata tekad atau kemauan yang tinggi yang ditunjang oleh struktur yang kuat belum mampu mengeluarkan mereka dari lembah kemiskinan.

\section{PENUTUP}

Adapun kesimpulan dari hasil penelitian adalah sebagai berikut:

1. Ketidakmampuan dalam menghadapi berbagia tuntutan di kota menyebabkan tanah-tanah di kota menjadi tempat tinggal seperti di bantaran rel kereta api. Kemiskinan yang terjadi di kawasan pemukiman kumuh bantaran rel kereta api disebabkan karen faktor individu dan struktural yang kerap menjerat mereka dalam lingkaran kemiskinan. Kemiskinan bukanlah keinginan seseorang, namun keasadaran manusia dan sebuah sistem yang tidak fungsional membuat mereka harus masuk dalam zona kemiskinan. Berbagai kebijakan yang sudah dilakukan pemerintah belum bisa menjadi sebuah solusi untuk memberantas kemiskinan. Meski masyarakat di bantaran rel kereta apI adalah masyarakat batak Toba yang memiliki jiwa dan semanagat yang kuat namun hambatan struktural menjebak mereka untuk keluar dari lingkaran kemiskinan.

1. Usaha-usaha yang mereka lakukan dengan berbagai strategi untuk keluar dari jerat kemiskinan justru membawa mereka dalam lingkran kemiskinan. Meski mereka mampu mengcukupi kebutuhan sehari-hari mereka namun sulit untuk memutus lingkaran kemiskinan tersebut. Kurangnya pendidikan dan keterampilan membawa mereka dalam pekerjaan yang berstatus rendah di perkotaan.

2. Kemiskinan perkotaan telah menjadi 'model' dari perkembangan kota, dan juga merupakan masalah bagi pemerintahan dan manajemen perkotaan. Karena dari cara hidup para migran di perkotaan inilah telah lahir pola adaptasi, nilai-nilai yang diyakini, respons dalam tindakan/sikap, dan polapola kelakuan yang khas penduduk miskin kota yang oleh para ahlinya disebut dengan kebudayaan kemiskinan. Sama halnya pada masyarakat migran di kawasan pemukiman bantaran rel kereta api Kelurahan Tegal Sari mandala II Medan.

Adapun yang menjadi saran dalam penelitian ini adalah:

1. Berdasarkan dari hasil penelitian yang dilakukan bahwa masyarakat di kawasan kumuh masih terjerat dalam lingkaran kemiskinan yang disebabkan oleh faktor individu dan struktural. Maka bagi masyarakat ini perlu lebih meningkatkan kesadaran akan kemiskinannya dan memperluas pergaulan. Pergaulan bisa diperluas dengan cara mendekatkan mereka dalam suatu ajang komunikasi dengan 
orang-orang di sekitar mereka yang telah sukses sehingga wawasan mereka menjadi terbuka lebih luas dalam melihat masa depan.

2. Kasus kemiskinan struktural juga bisa dicari pemecahannya dengan cara memanfaatkan ikatan kekerabatan yang ada. Masyarakat batak Toba terkenal dengan ikatan kekerabatannya, maka dari itu mereka yang masih terjerat dalam kemiskinan dapat memanfaatkan ikatan kekerabatan dengan melibatkan diri dengan hubungan kerjasama dengan kerabat-kerabat yang tergolong kaya.

3. Bantuan pihak luar dan pemerintah masih diperlukan. Aset yang mereka miliki dan strategi bertahan hidup yang mereka lakukan masih sulit untuk mengeluarkan mereka dari jerat kemiskinan. Sebaiknya bantuan yang diberikan dalam bentuk keterampilan dan kerja keras serta penyuluhan yang berhubungan dengan etos kerja dan aplikasi nilainilai yang mendorong pembangunan. Dari pengakuan masyarakat bahwa bantuan- bantuan dari pemerintah mbelum sampai ke daerah ini secara merata. Dengan demikian kemiskinan bisa diputus sehingga ada peluang bagi mereka untuk keluar dari jerat kemiskinan.

\section{DAFTAR PUSTAKA}

Badan Perencanaan dan Pembangunan Daerah (BAPEDA). 2011. Penyusunan Strategi Penanggulangan Kemiskinan di Kabupaten Blitar 2011-2016. Blitar

Departemen komunikasi dan Informatika. Jurnal Dialog Kebijakan Publik: 2008

Departemen komunikasi dan Informatika. Jurnal Dialog Kebijakan Publik: 2012

Kanarji \& Sudarso. 2005. Penelitian Model Pengentasan Kemiskinan Melalui Peran Serta Masyarakat Mampu di Provinsi Jawa Timur. Surabaya: Lutfansah

Lembaga Penelitian, Pendidikan dan Penerangan Ekonomi dan Sosial. 1984. Gelandangan Pandangan Ilmu Sosial. Jakarta : Midas Surya Grafindo

Menno, S dan Mustamin Alwi. Antropologi Perkotaan. 1994. Jakarta: PT Raja Grafindo Persada

Moleong, Lexy. Metode Penelitian Kualitatif. 2010. Bandung: PT Remaja Rosdakarya

Ritzer, George. 2008. Teori Sosiologi Modern. Jakarta: Kencana
Setiawati, Endah. 2000. Orientasi Nilai Budaya Penghuni Pemukiman Kumuh. Bogor:

Fakultas Pertanian Institut Pertanian Bogor

Simanjuntak, Bungaran Antonius dan J. Nasikoen. 2008. Kapita Selekta Teori-Teori Antropologi dan Sejarah Sosiologi. Medan: Bina Media Perintis

Soekanto, Soerjono. 2000. Sosiologi Suatu Pengantar. Jakarta: PT Raja Grafindo

Suharto, Edi. 2009. Kemiskinan dan Perlindungan Sosial di Indonesia. Bandung: Alfabeta

Sumarmi, Mamik.2010. Jurnal Survival Mechanism Victim Housland of Lumpur Lapindo in Sidoarjo, Jawa Timur. Surabaya: UPBJ-UT

Wignjosoebroto, Soetandyo \& Bagang Suyanto. 2005. Upaya Penaggulangan Kemiskinan \& Pengangguran di Propinsi Jawa Timur. Surabaya: Lutfansah 